\title{
4,4'-Methylenebis(2-chloroaniline) (MBOCA) May Be Highly Toxic and a Carcinogen Based on an Experimental Study with Mice
}

\author{
Hong-I Chen ${ }^{1}$, Tzong-Cherng Chi' ${ }^{1}$, Shun-Yao Ko ${ }^{1}$, Yi-Chiang Hsu ${ }^{1}$, I-Hsuan Lin ${ }^{1}$, Ann Chen ${ }^{2}$, \\ Saou-Hsing Liou ${ }^{3}$, Chien-Feng $\mathrm{Li}^{4}$ \\ ${ }^{1}$ Graduate Institute of Medical Sciences, Chang Jung Christian University, Tainan, Taiwan \\ ${ }^{2}$ Department of Pathology, Tri-Service General Hospital, National Defense Medical Center, Taipei, Taiwan \\ ${ }^{3}$ Division of Environmental Health and Occupational Medicine, National Health Research Institutes, Zhunan, \\ Taiwan \\ ${ }^{4}$ Department of Pathology, Chi-Mei Medical Center, Tainan, Taiwan \\ Email: ${ }^{\text {hong-i@mail.ndmctsgh.edu.tw, }}$, $\underline{\text { hichen@mail.cjcu.edu.tw }}$
}

Received 26 February 2014; revised 1 April 2014; accepted 9 April 2014

Copyright (C) 2014 by authors and Scientific Research Publishing Inc.

This work is licensed under the Creative Commons Attribution International License (CC BY).

http://creativecommons.org/licenses/by/4.0/

(c) (i) Open Access

\begin{abstract}
4,4'-Methylenebis(2-chloroaniline) (MBOCA) is a probable human carcinogen. Few studies have been performed regarding the genotoxicity of $M B C O A$, and the MBOCA metabolic pathway is not fully understood. We treated four-week-old ICR male mice weighing 25 - $30 \mathrm{~g}$ with MBOCA and observed the effects of MBOCA on the internal organs. It can be concluded that MBOCA is a carcinogen and also affects gene regulation. Oral or topical administration of $50 \mathrm{mg} / \mathrm{kg}, 100 \mathrm{mg} / \mathrm{kg} \mathrm{or}$ $200 \mathrm{mg} / \mathrm{kg}$ MBOCA resulted in 56\% - 81\% of mice showing unusual inflammation, degeneration, and dysplasia in kidney, liver, stomach, intestine and urinary bladder based on histology. Furthermore, we investigated the association between oxidative DNA damage and MBOCA exposure by measuring plasma level of 8-hydroxydeoxyguanosine (8-0HdG). The results showed that the MBOCA-treated mice had significantly higher 8-OHdG levels than the control mice. This study confirms that MBOCA is potentially carcinogenic and highly toxic to both animals and humans.
\end{abstract}

\section{Keywords}

4,4'-Methylenebis(2-chloroaniline), MBOCA, Transitional Cell Carcinoma of Bladder, Oxidative DNA Damage, 8-Hydroxydeoxyguanosine (8-0HdG)

\footnotetext{
${ }^{*}$ Corresponding author.
}

How to cite this paper: Chen, H.-I, et al. (2014) 4,4'-Methylenebis(2-chloroaniline) (MBOCA) May Be Highly Toxic and a Carcinogen Based on an Experimental Study with Mice. Advances in Biological Chemistry, 4, 203-213. 


\section{Introduction}

4,4'-Methylenebis(2-chloroaniline) (MBOCA) is an aromatic diamine used as a curing agent for polyurethane and epoxy resins. It has several of the general toxicity characteristics of aromatic amines and is most likely a human carcinogen. Methaemoglobinemia and the resulting cyanosis, which are hallmark symptoms of exposure to aromatic amines, are reported with much less frequency after exposure to MBOCA [1]. Workers may inhale small particles of MBOCA in the air or absorb the agent through the skin if they come into contact with MBOCA dust or vapour. Acute exposure to high levels of MBOCA can cause eye and skin irritation in humans [2] [3]. The most notable risk factor for the development of lower urinary tract cancers is occupational exposure to aromatic amines, first noted in England in 1895 [4]. The International Agency for Research on Cancer [5] and the US Environmental Protection Agency have determined that MBOCA is a toxic substance (category 2A; Agency for Toxic Substances and Disease Registry, ATSDR, 1994) [6]. In addition, in a report on carcinogens, the National Toxicology Program reported that MBOCA might reasonably be anticipated to be a human carcinogen [7]; however, the US Environmental Protection Agency has no information on the chronic effects of MBOCA in humans [8]. Moreover, the data available from epidemiological studies are inadequate to evaluate the relationship between human cancer and exposure to MBOCA specifically [9].

A sentinel case of transitional cell carcinoma of the urinary bladder was diagnosed in an MBOCA manufacturing factory in Taiwan in 2005 [10]. However, it remains unclear whether MBOCA causes malignancy.

We performed animal studies with MBOCA-treated ICR male mice. The animals were treated with MBOCA by three different exposed routes, topical skin smear, feeding and intraperitoneal injection. After the mice were sacrificed, the lung, kidney, liver, stomach, intestine and urinary bladder were observed histologically. We also collected the plasma from the mice to determine whether the MBOCA causes oxidative stress based on indicators, such as 8-OHdG. These results support the conclusion that MBOCA is a carcinogen and highly toxic to both animals and humans.

\section{Materials and Methods}

\subsection{Drugs}

For the mouse model experiment, MBOCA (Sigma-Aldrich) was dissolved in dimethyl sulphoxide (DMSO, Sigma-Aldrich) and diluted with $60 \%$ alcohol. Different concentrations of drug were administered to the mice via intraperitoneal injection, drinking water or topical skin smear.

\subsection{Animal Models}

Four-week-old ICR male mice weighing approximately 25 - $30 \mathrm{~g}$ were used for the experiments. The mice were housed in individually ventilated cages in a temperature-controlled room with a $12 \mathrm{~h} \mathrm{light/dark}$ cycle and allowed access to food and water. The ICR male mice were purchased from Biolasco Taiwan Co. Ltd. The MBOCA was dissolved in DMSO and diluted with $60 \%$ alcohol. The mice were treated with $50 \mathrm{mg} / \mathrm{kg}, 100$ $\mathrm{mg} / \mathrm{kg}$ and $200 \mathrm{mg} / \mathrm{kg}$ via different routes [2] [11]. There were 6 - 10 mice per dose in each experiment as follows:

A. Intraperitoneal injection: $100 \mathrm{mg} / \mathrm{kg}$ or $200 \mathrm{mg} / \mathrm{kg}$, once/day for ten days. All mice were dead 6 - 18 days later.

B. Oral feeding: the drinking water contained $50 \mathrm{mg} / \mathrm{kg}, 100 \mathrm{mg} / \mathrm{kg}$, or $200 \mathrm{mg} / \mathrm{kg}$ MBOCA and the mice were feed once/day for three months. The mice were then returned to normal feeding with MBOCA-free water for six months.

C. Topical: topical skin smear on shaved abdominal skin with a dose of $100 \mathrm{mg} / \mathrm{kg}$ or $200 \mathrm{mg} / \mathrm{kg}$ once/day for three months.

The oral and topical groups were sacrificed six months after the last administration of MBOCA. The lung, liver, kidney, stomach, intestine and urinary bladder were excised for histology.

The control group mice were provided MBOCA-free diet for oral administration or DMSO with $100 \mathrm{mg} / \mathrm{kg}$ for intraperitoneal injection, oral feeding and skin smear.

\subsection{Histomorphology}

Tissue specimens were collected and fixed in 10\% neutral phosphate-buffered formalin (NBF; formalin/tissue 
ratio, 10:1) overnight and processed for $8 \mathrm{~h}$ (30 min/stage) according to the paraffin-embedding procedure with a Tissue-Tek VIP IV automated tissue processor (Sakura Finetek USA, Inc.; Torrance, CA) before embedding in paraffin and sectioning into $4 \mu \mathrm{m}$ tissue sections as described previously [12]-[14]. To examine morphological changes, haematoxylin and eosin (H\&E) staining was performed on each tissue section. The stained sections were viewed and photomicrographs were taken with a light microscope (Olympus, Japan).

\subsection{Measurement of Plasma 8-OHdG Levels}

Blood was collected from the orbital sinus prior to MBOCA exposure and four or five months after the last MBOCA administration. Blood was also collected from the unexposed mouse groups (control or DMSO only). The samples were centrifuged at $12,000 \mathrm{rpm}$ at $4^{\circ} \mathrm{C}$, and then stored at $-80^{\circ} \mathrm{C}$. The serum 8-hydroxydeoxyguanosine (8-OHdG) was measured according to the instructions of the 8-hydroxy-2-deoxy guanosine EIA Kit (96-well kit) (Cayman Chemical, USA). The results were measured with an ELISA (enzyme-linked immunosorbent assay) Reader (Synergy HT, Bio-TEK) at $412 \mathrm{~nm}$.

First, the EIA buffer and wash buffer were prepared with ultrapure water. The EIA buffer concentrate (10X) was diluted with 90 ultrapure water. The wash buffer concentrate (400X) was diluted with $2 \mathrm{l}$ of water and $1 \mathrm{ml}$ polysorbate 20 was added. The 8-hydroxy-2-deoxy guanosine EIA standard was prepared with EIA buffer. The standard concentrations were as follows: $3000 \mathrm{pg} / \mathrm{ml}, 1333 \mathrm{pg} / \mathrm{ml}, 592.6 \mathrm{pg} / \mathrm{ml}, 263.4 \mathrm{pg} / \mathrm{ml}, 117.1 \mathrm{pg} / \mathrm{ml}, 52$ $\mathrm{pg} / \mathrm{ml}, 23.1 \mathrm{pg} / \mathrm{ml}$, and $10.3 \mathrm{pg} / \mathrm{ml}$ (S1-S8). All diluted standards were stored at $4^{\circ} \mathrm{C}$. The 8-hydroxy-2-deoxy guanosine AChE tracer and 8-hydroxy-2-deoxy guanosine EIA monoclonal antibody were then prepared with 6 ml EIA buffer. The reagents EIA buffer, 8-hydroxy-2-deoxy guanosine EIA standard, samples, 8-hydroxy2-deoxy guanosine AChE tracer, and 8-hydroxy-2-deoxy guanosine EIA monoclonal antibody, were added. The plate was covered with plastic film and incubated for $18 \mathrm{~h}$ at $4{ }^{\circ} \mathrm{C}$. The Ellman's reagent was prepared immediately before use by reconstituting with $20 \mathrm{ml}$ ultrapure water. The wells were washed five times with wash buffer, and Ellman's reagent was added to each well with tracer to determine the total activity in the wells. The plate was covered with plastic film. Optimum development is obtained by using a shaker and developing the plate in the dark. This assay must be developed within 90 - $120 \mathrm{~min}$. The final enzymatic reaction product has is yellow and is read at $412 \mathrm{~nm}$. The results were calculated from a standard curve.

\subsection{Statistical Analyses}

Statistical evaluations were performed using Graph Pad Prism 5.0. The Student's t test was used to compare the distribution of characteristics between the exposed and control groups. Values of $p<0.05$ were considered statistically significant.

\section{Results}

In this study, 84 mice were used, including the control group (6 mice), DMSO group (18 mice) and MBOCAtreated mice (60 mice).

\subsection{Animal Model and Histological Results}

In the intraperitoneal injection group, eight mice received $200 \mathrm{mg} / \mathrm{kg}$ MBOCA once/day for 10 days and all died 6 - 9 days later. An additional six mice received $100 \mathrm{mg} / \mathrm{kg}$ once/day for 10 days and also died 8 - 18 days later. The visceral organs of the dead mice showed necrosis, and a solid form of the injected fluid was also occasionally observed (Figure 1(A)). There was no tissue change in the intraperitoneal injection group that six mice received DMSO only (100 mg/kg).

In the oral group, three subgroups of mice received the MBOCA via the drinking water at doses of 50 $\mathrm{mg} / \mathrm{kg} / \mathrm{day}, 100 \mathrm{mg} / \mathrm{kg} / \mathrm{day}$ or $200 \mathrm{mg} / \mathrm{kg} /$ day for three months. Each subgroup included 8 - 10 mice. The low dose $(50 \mathrm{mg} / \mathrm{kg} /$ day) of MBOCA caused $10 \%$ mortality (1/10 mice). The $100 \mathrm{mg} / \mathrm{kg} /$ day dose caused $22.2 \%$ mortality (2/9 mice) and the $200 \mathrm{mg} / \mathrm{kg} /$ day dose caused $100 \%$ mortality ( $8 / 8$ mice) within four months after three months of feeding. We examined the dead mice and observed swelling and distension of the intestine (Figure 1(B) and Figure 1(C)). After the mice were sacrificed, histological degeneration or dysplasia of the liver, stomach, intestine, kidney or bladder cells was observed (Figures 2-4). There was no tissue change in the oral group that six mice received DMSO only (100 mg/kg). 

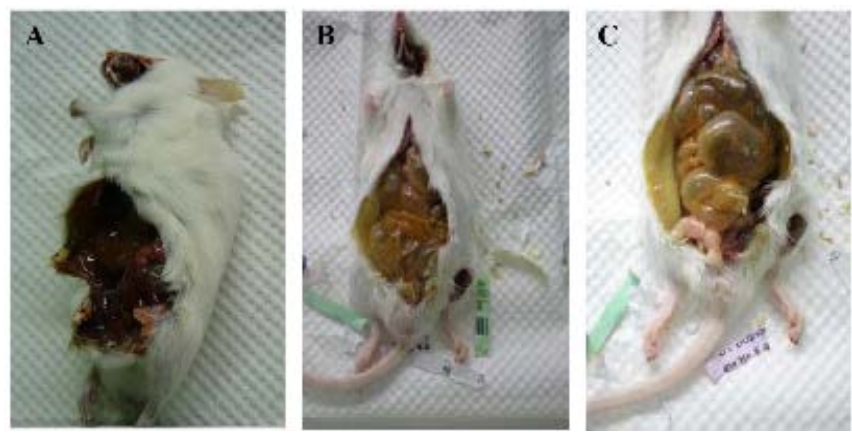

Figure 1. Dead mice after intraperitoneal injection or oral feeding of MBOCA. (A) Visceral organs reveal necrosis after intraperitoneal injection; (B) and (C) Swelling and distension of the intestine after oral administration.
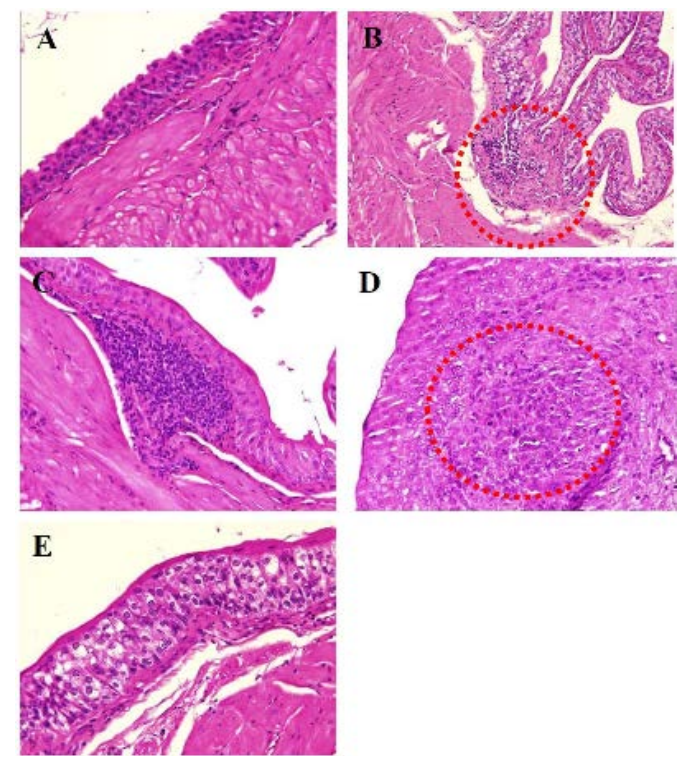

Figure 2. Comparison of bladder cells before and after MBOCA treatment (H\&E staining, original magnification, 100×). (A) Normal bladder tissue; (B) Superficial invasion (circle); (C) Chronic inflammation; (D) Deep invasion (circle); (E) Flat dysplasia.
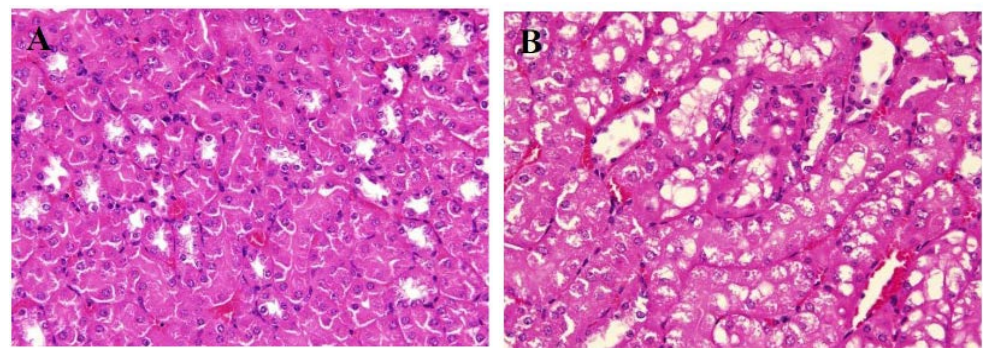

Figure 3. Comparison of renal cells before and after MBOCA treatment (H\&E staining, original magnification, 400×). (A) Normal renal cell; (B) Renal tubules with degeneration (vacuolation and tubular cell damage).

In the topical group, two subgroups of mice received $100 \mathrm{mg} / \mathrm{kg}$ (nine mice) once/day or $200 \mathrm{mg} / \mathrm{kg}$ (ten mice) once/day MBOCA for three months via skin smear. One mouse that received $200 \mathrm{mg} / \mathrm{kg} /$ day MBOCA died 

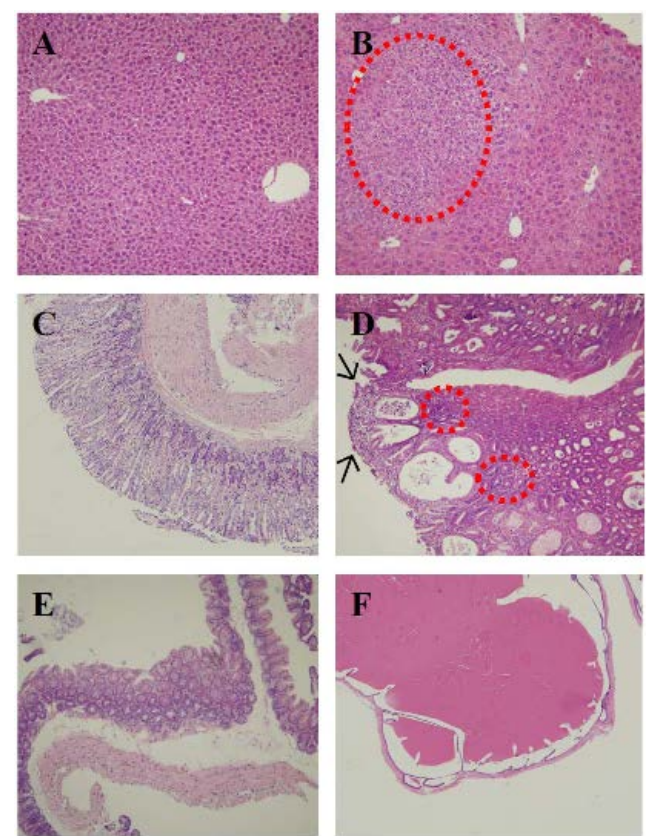

Figure 4. Comparison of liver cells, stomach and intestine before and after MBOCA treatment (H\&E staining, original magnification, 100×). (A) Normal liver cell; (B) Liver cell dysplasia (circle); (C) Normal stomach; (D) Ulceration (arrows) with dysplasia (circles) of stomach; (E) Normal intestine; (F) Dilatation of intestine.

(10\% mortality) three to four months after the last administration of MBOCA. The liver, stomach, intestine, kidney, and urinary bladder of the sacrificed mice were histologically examined. Inflammation, degeneration or cell dysplasia invasion in very similar to the oral group were observed in the individual organs (Figures 2-4). There was no tissue change in the skin smear group that six mice received DMSO only (100 mg/kg). No histological change of the lung in these studies including oral or topical group was found.

\subsection{Comparison of Plasma 8-0HdG Levels}

The plasma 8-OHdG levels showed that the MBOCA-treated mice had significantly higher 8-OHdG levels than the control or DMSO only mice. The plasma 8-OHdG levels in the study are shown in Figures 5-7.

Figure 5(a) \& Figure 5(b) show that 8-OHdG was detected in the plasma after oral administration of 50 $\mathrm{mg} / \mathrm{kg}$ or $100 \mathrm{mg} / \mathrm{kg}$ MBOCA for three months. The samples were collected from the orbital sinus of the mice four and five months after the last administration of MBOCA. Samples were also collected from the unexposed mice, including the control and DMSO only mice. The 8-OHdG levels increased at five months compared to the control for the $50 \mathrm{mg} / \mathrm{kg}$ MBOCA group $(p<0.05$ ) (Figure 5(a)), and the 8-OHdG levels increased for the 100 $\mathrm{mg} / \mathrm{kg}$ MBOCA group at both four and five months $(p<0.05$ ) (Figure 5(b)). Comparison of the 8-OHdG levels between months 4 and 5 after $50 \mathrm{mg} / \mathrm{kg}$ or $100 \mathrm{mg} / \mathrm{kg}$ MBOCA administration in the oral feeding group indicated that the 8-OHdG levels increased (50 mg/kg, $100 \mathrm{mg} / \mathrm{kg}$ ) at month $5(p<0.01, p<0.05)$ (Figure 5 (c) and Figure 5(d)).

Figure 6(a) shows that plasma 8-OHdG was detected in the mice that received a skin smear of $100 \mathrm{mg} / \mathrm{kg}$ MBOCA for three months. The samples were collected from the orbital sinus of the mice four and five months after the last administration of MBOCA. Samples were also collected from the unexposed mice (control). The 8-OHdG levels increased at months 4 and 5 vs the control group $(p<0.05, p<0.01)$. Additionally, the 8-OHdG levels increased at month 5 vs the control for the $200 \mathrm{mg} / \mathrm{kg}$ MBOCA group $(p<0.01)$ (Figure 6(b)). Comparison of the 8-OHdG levels between months 4 and 5 after the administration of $100 \mathrm{mg} / \mathrm{kg}$ or $200 \mathrm{mg} / \mathrm{kg}$ MBOCA via skin smear showed that the 8-OHdG levels increased at month $5(p<0.01, p<0.05)$ (Figure 6(c) and 


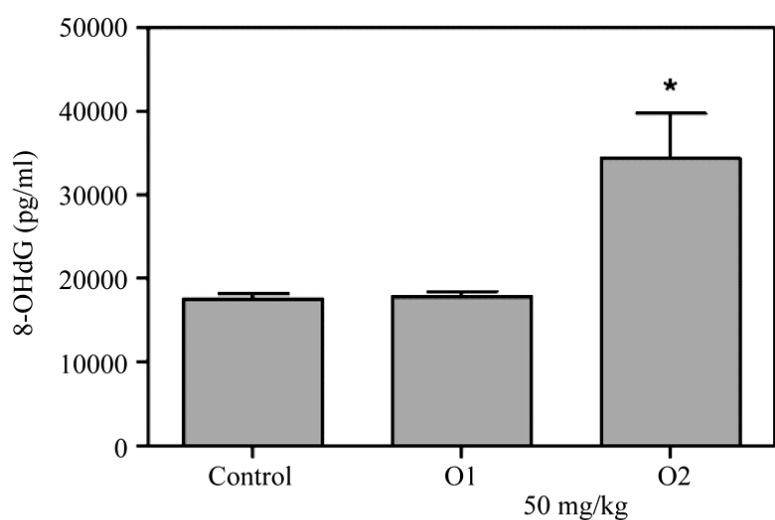

(a)

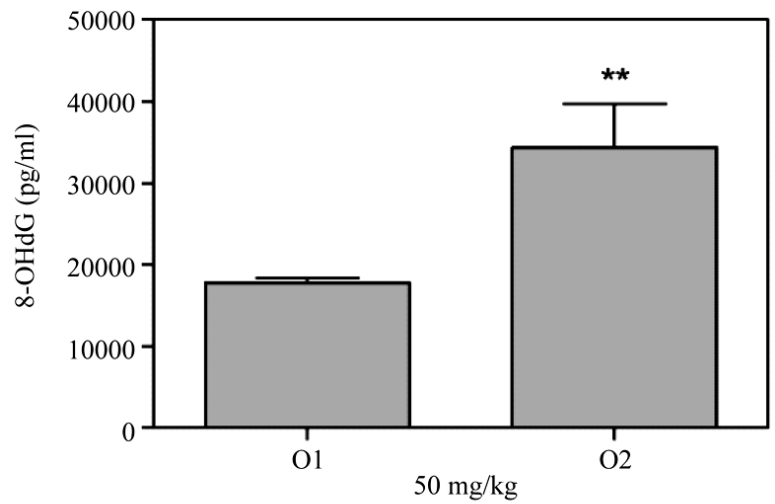

(c)

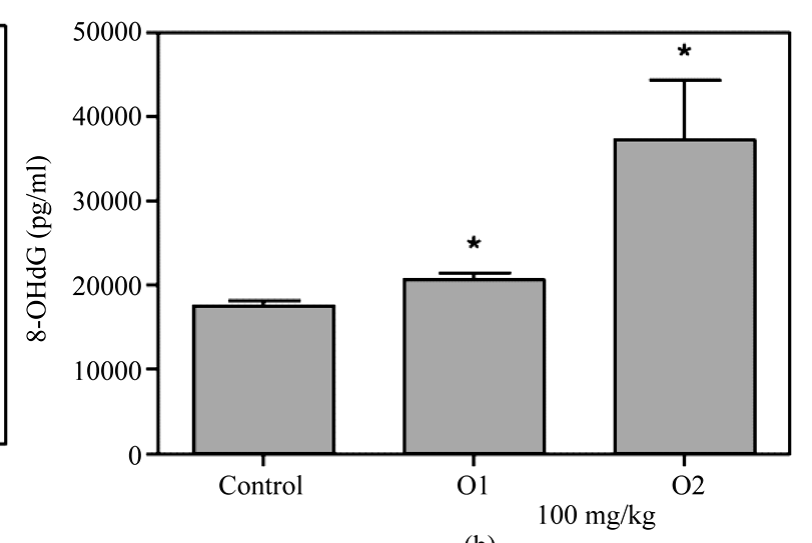

(b)

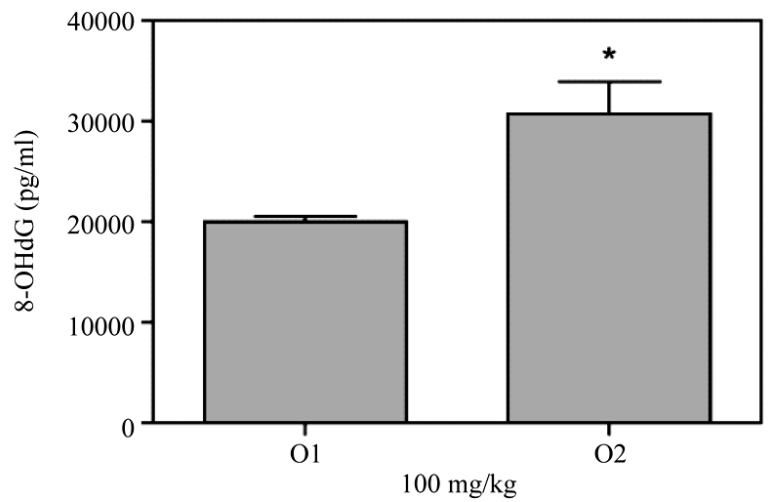

(d)

Figure 5. 8-OHdG levels measured after MBOCA oral feeding. (a) The plasma 8-OHdG levels were detected after oral administration of $50 \mathrm{mg} / \mathrm{kg} /$ day MBOCA for three months. The samples were collected 4 (O1) and $5(\mathrm{O} 2)$ months after the last administration of MBOCA from the treated and unexposed mice (control). O1 $p=0.824$, O2 $p=0.0331\left({ }^{*} p<0.05\right.$ vs control); (b) The plasma 8-OHdG levels were detected after oral administration of $100 \mathrm{mg} / \mathrm{kg} /$ day MBOCA for three months. The samples were collected $4(\mathrm{O} 1)$ and $5(\mathrm{O} 2)$ months after the last administration of MBOCA from the treated and unexposed mice (control). O1 $p=0.0119, \mathrm{O} 2 p=0.0132$ ( ${ }^{*} p<0.05$ vs control); (c) Comparison of plasma 8-OHG levels 4 (O1) and 5 (O2) months after the last administration of $50 \mathrm{mg} / \mathrm{kg} /$ day MBOCA. $p=0.0088\left({ }^{* *} p<0.01\right)$; (d) Comparison of plasma 8-OHG levels 4 (O1) and 5 (O2) months after the last administration of $100 \mathrm{mg} / \mathrm{kg} /$ day MBOCA. $p=0.048\left(^{*} p<\right.$ $0.05)$.

Figure 6(d)). In addition, there was no significant difference between the different doses for either the skin smear or oral administration (Figure 7). There was also no difference in the 8-OHdG levels between the control and DMSO groups.

\section{Discussion}

We previously reported one incidence of MBOCA-induced bladder cancer in a 52-yr-old male who had worked in one of the four MBOCA production companies for 14 years [10]. In addition, we conducted a bladder cancer screening program in the four MBOCA producing factories [15]. Although the production of MBOCA in the United States ceased in 1982, it was first listed in the Third Annual Report on Carcinogens in 1983 [7], and MBOCA continues to be manufactured in other countries. In studies of workers exposed to MBOCA in the United States and Taiwan, cases of urinary-bladder cancer were detected in a screening program [15] [16]; however, there is inadequate evidence in humans for the carcinogenicity of MBOCA [17]. In a small UK cohort of male MBOCA production workers, one urinary bladder cancer death was reported, yielding a statistically nonsignificant five-fold increase in mortality and a three-fold increase in incidence compared to national rates [18]. Therefore, the health impact of MBOCA remains a concern in occupational settings in many countries.

Pure MBOCA is also known as methylene-bis-ortho-chloroaniline or MOCA and is a colourless solid. However, MBOCA is usually coloured during the manufacturing process as yellow, tan, or brown pellets. MBOCA 


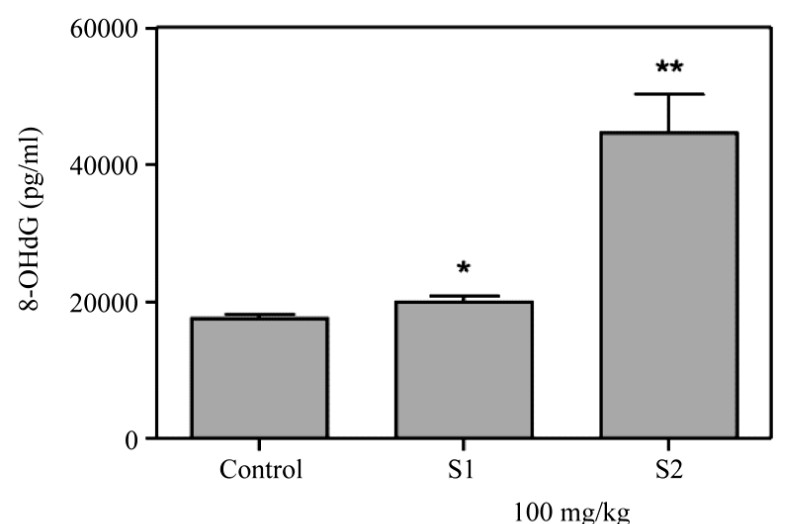

(a)

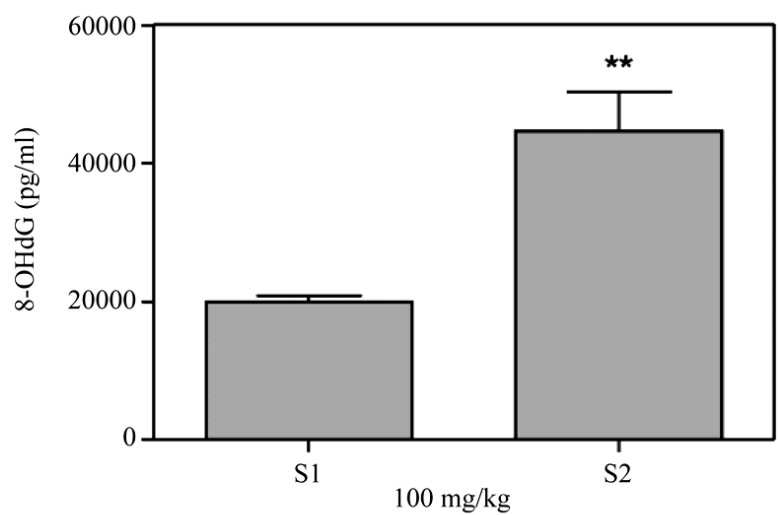

(c)

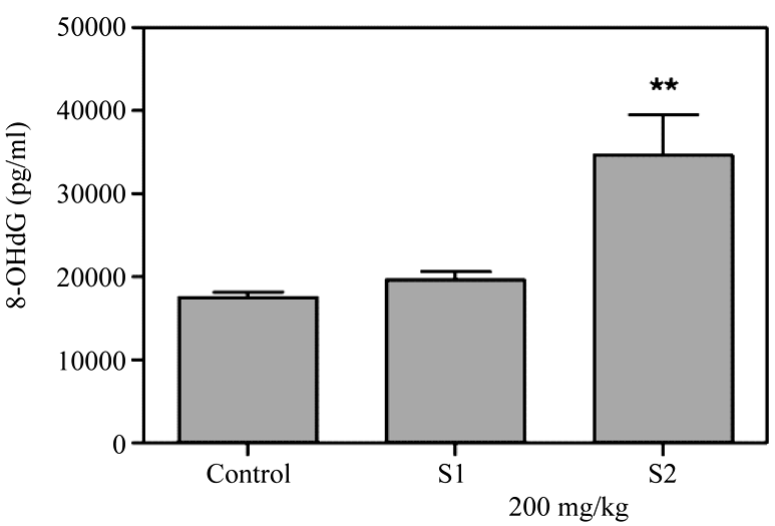

(b)

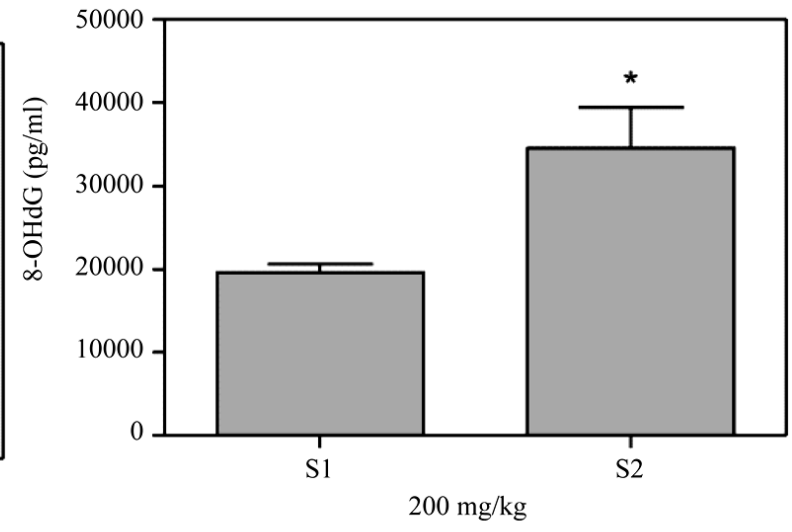

(d)

Figure 6. 8-OHdG levels measured after MBOCA skin smear. (a) The plasma 8-OHdG levels were detected in mice that received $100 \mathrm{mg} / \mathrm{kg} /$ day MBOCA for three months via skin smear on the shaved abdomen. The samples were collected 4 (S1) and 5 (S2) months after the last administration of MBOCA from the treated and unexposed mice (control). S1 $p=0.0343$, S2 $p=0.0013\left({ }^{*} p<0.05,{ }^{* *} p<0.01\right.$ vs control); (b) The plasma 8-OHdG levels were detected in mice that received 200 $\mathrm{mg} / \mathrm{kg} /$ day MBOCA for three months via skin smear on the shaved abdomen. The samples were collected 4 (S1) and 5 (S2) months after the last administration of MBOCA from the treated and unexposed mice (control). S1 $p=0.1017, \mathrm{~S} 2 p=0.0091$ ( ${ }^{* *} p<0.01$ vs control); (c) Comparison of plasma 8-OHG levels 4 (S1) and 5 (S2) months after the last administration of 100 $\mathrm{mg} / \mathrm{kg} /$ day MBOCA. $p=0.0030\left({ }^{* *} p<0.01\right)$; (d) Comparison of plasma 8-OHG levels 4 (S1) and 5 (S2) months after the last administration of $200 \mathrm{mg} / \mathrm{kg} /$ day MBOCA. $p=0.0296\left({ }^{*} p<0.05\right)$.

has no odour or taste [6]. Its chemical formula is $\mathrm{C}_{13} \mathrm{H}_{12} \mathrm{Cl}_{2} \mathrm{~N}_{2}$, and the molecular weight is $267.15 \mathrm{~g} / \mathrm{mol}$ [17]. MBOCA is used widely as a curing agent in the manufacturing of polyurethane elastomers. In addition to producing castable polyurethane parts, MBOCA is also applied as a coating in chemical reactions to "set” glues, plastics, and adhesives. There is also no information regarding the daily dose of MBOCA to which workers were exposed or the route of exposure [6]. Although the literature reports urinary bladder tumours in dogs exposed to MBOCA [19], few studies have been performed on the genotoxicity of MBCOA. However, the carcinogenicity of MBOCA leading to the development of bladder cancer and other cancers are unclear.

In the first group of studies, 14 mice received MBOCA via intraperitoneal injection (eight with $100 \mathrm{mg} / \mathrm{kg}$ or six with $200 \mathrm{mg} / \mathrm{kg}$ ) for 10 days. All the mice were dead 6 - 18 days later. Necrotic small intestines were observed in all the dead mice. Tobes et al. reported that $1 \mathrm{~h}$ after a single intravenous dose of $0.49 \mathrm{mg} / \mathrm{kg}$ radiolabeled MBOCA to rats, radioactivity was found in the tissues in the following order: small intestine $>$ liver $>$ fat tissue $>$ lungs $>$ kidneys $>$ skin $>$ adrenals [20]. Similar results for liver accumulation were obtained in rats $48 \mathrm{~h}$ after an intraperitoneal injection of $1 \mathrm{mg} / \mathrm{kg}$ radioactive MBOCA [21]. The results of our experiments, such as the visceral necrosis and swelling intestines provide strong evidence that MBOCA has a genotoxic effect on the small intestines of mice. However, the detailed mechanism of MBOCA genotoxicity must be further investigated.

In the oral group, a dose-dependent increase in mortality was observed in the mice fed 50, 100, or 200 


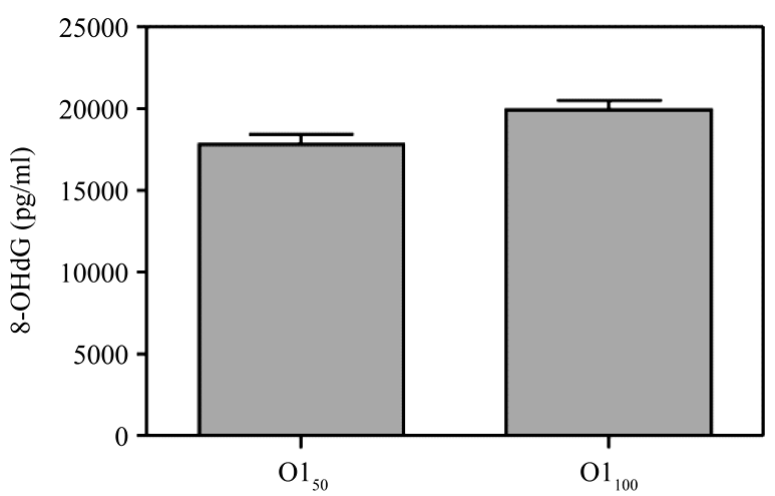

(a)

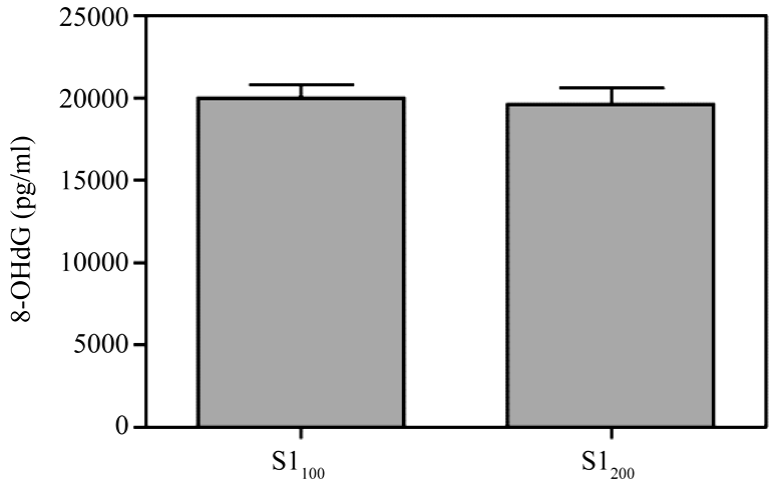

(c)

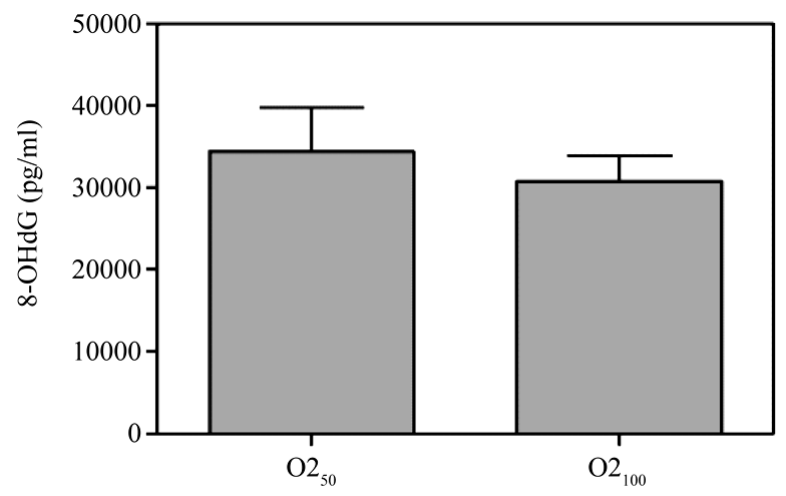

(b)

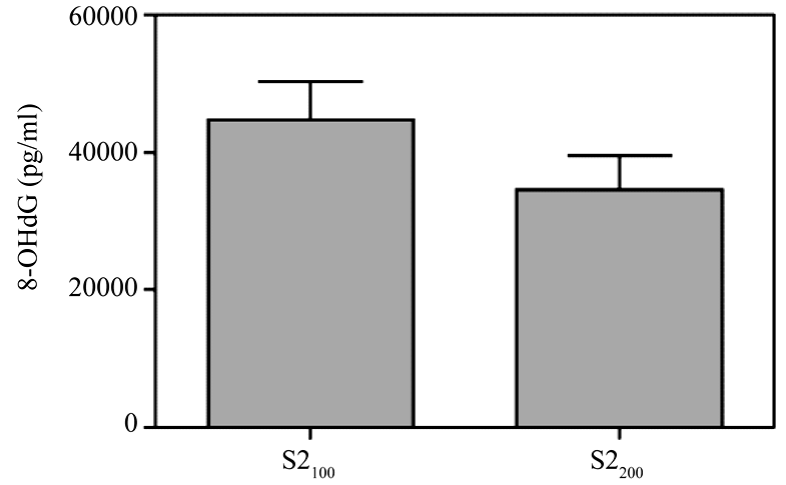

(d)

Figure 7. Comparison of 8-OHdG levels at the same time between different doses of MBOCA administration via oral feeding and skin smear. (a) $\mathrm{O}_{50}=$ Sample collection four months after the last administration of $50 \mathrm{mg} / \mathrm{kg} /$ day MBOCA via oral administration for three months, $\mathrm{O}_{100}=$ Sample collection four months after the last administration of $100 \mathrm{mg} / \mathrm{kg} / \mathrm{day}$ MBOCA via oral administration for three months. $p=0.0708$; (b) $\mathrm{O} 2_{50}=$ Sample collection five months after the last administration of $50 \mathrm{mg} / \mathrm{kg} /$ day MBOCA via oral administration for three months, $\mathrm{O}_{100}=$ Sample collection five months after the last administration of $100 \mathrm{mg} / \mathrm{kg} /$ day MBOCA via oral administration for three months. $p=0.6939$; (c) $\mathrm{S} 1_{100}=\mathrm{Sample}$ collection four months after the last administration of $100 \mathrm{mg} / \mathrm{kg} /$ day MBOCA via skin smear for three months, $\mathrm{S} 1_{200}=$ Sample collection four months after the last administration of $200 \mathrm{mg} / \mathrm{kg} /$ day MBOCA via skin smear for three months. $p=$ 0.7628; (d) S2 100 = Sample collection five months after the last administration of $100 \mathrm{mg} / \mathrm{kg} /$ day MBOCA via skin smear for three months, $\mathrm{S}_{200}=$ Sample collection five months after the last administration of $200 \mathrm{mg} / \mathrm{kg} /$ day MBOCA via skin smear for three months. $p=0.201$.

$\mathrm{mg} / \mathrm{kg} /$ day MBOCA for three months. We examined the dead mice and observed swelling and distension of the intestine. After the mice remaining surviving mice were sacrificed, chronic inflammation, degeneration or dysplasia (premalignant stage) of the cells of the liver $(13 / 16,81.25 \%)$, stomach $(12 / 16,75 \%)$, intestine $(10 / 16$, $62.5 \%)$, kidney (9/16, 56.25\%), or bladder (9/16, 56.25\%) was observed in 16 sacrificed mice (50 mg/kg/day or $100 \mathrm{mg} / \mathrm{kg} /$ day).

Although MBOCA studies in rats, mice, and dogs reported a carcinogenic response after chronic exposure to MBOCA, there have been no additional carcinogenicity studies in animals since the most recent evaluation [17] [22]. Lungs, liver, and urinary bladder were the primary target organs for cancer in these species. A dose-dependent increase in lung tumours was observed in Sprague-Dawley rats fed 12.5, 25, or $50 \mathrm{mg} / \mathrm{kg} / \mathrm{day}$ MBOCA for 18 months, and the incidence of lung tumours was 23\%, 37\%, and 70\%, respectively [23]. A similar observation (presence of lung adenocarcinomas) was made in Charles River rats fed $50 \mathrm{mg} / \mathrm{kg} / \mathrm{day}$ MBOCA for 2 years [11]. In another study, male Charles River CD-1 rats were fed 25 or 50 mg/kg/day MBOCA for 18 months. The authors reported lung adenocarcinoma in 1/22 and 1/19 animals, respectively [2], although this finding was not statistically significant. Oral administration of MBOCA to male and female rats increased the incidence of hepatomas and lung tumours [24]. A limitation of this study was the small number of animals on which the tumour incidence was based. These studies were also performed with animals fed standard protein diets. The results of our oral feeding experiments indicate that MBOCA may reasonably be a mouse carcinogen. The mice 
that died prior to sacrifice indicated high genotoxicity with higher doses $(100 \mathrm{mg} / \mathrm{kg} / \mathrm{day}$ or $200 \mathrm{mg} / \mathrm{kg} / \mathrm{day})$ of MBOCA.

In the topical group, histomorphological changes including inflammation, degeneration, dysplasia and deep invasion in the liver $(14 / 1877.78 \%)$, stomach $(12 / 18,66.67 \%)$, intestine $(11 / 18,61.11 \%)$, kidney $(10 / 18$, $55.56 \%)$, or bladder $(10 / 18,55.56 \%)$ of the 18 sacrificed mice $(100 \mathrm{mg} / \mathrm{kg} /$ day or $200 \mathrm{mg} / \mathrm{kg} /$ day) were observed. This suggests that the skin absorbed MBOCA and the MBOCA was transferred to the liver, stomach, intestine, kidney and urinary bladder by the circulatory system, resulting in histomorphological changes of the cells. There were several cases of dysplasia and potential malignancy. Although we found that there was no histological change of the lung in these studies including oral or topical group, the reason may be too short time to induce the genotoxic effect on the lung.

Nesnow et al. used the mouse skin assay to evaluate the genotoxicity and carcinogenicity of MBOCA in the presence of 12-o-tetradecanoylphorbol-U-acetate (TPA) as a tumour promoter [15] [25]. There are several limitations to this study. It was not clear whether TPA was administered to the control animals, whether the MBOCA was applied to shaved skin, or whether the area was protected after treatment. Another study reported that subcutaneous injection of MBOCA produced an increased incidence in hepatocellular carcinoma and lung cancer in rats [26]. After dermal application, MBOCA was neither an initiator nor a promoter in the two experiments in mice [27].

It was recently proposed that chemical carcinogenesis may involve the formation of chemical adducts in DNA through covalent binding based on the finding that MBOCA produces DNA adducts in rat liver at levels characteristic of genotoxic carcinogens [28]. The plasma 8-OHdG levels were measured to determine whether MBOCA causes oxidative stress. Analysis of 8-OHdG levels was performed by ELISA because ELISAs are easy, rapid, and require little equipment, analysis time, sample preparation, and sample validation, although ELISA sensitivity is lower than the liquid chromatography tandem mass spectrometry (LC/MS/MS) method [29]. The plasma 8-hydroxydeoxyguanosine (8-OHdG) levels showed that the MBOCA-treated mice had significantly higher 8-OHdG levels than the control mice and were also different between the mice. However, there was no significant difference between the skin smear and oral feeding method. This indicates that MBOCA increases 8-OHdG levels as long as it remains in the mice, but has no effect even at higher doses.

In conclusion, pathological changes in the liver, kidney and urinary bladder of MBOCA-treated mice revealed unusual lesions of inflammatory degeneration and malignant change. The present studies confirm that MBOCA is potentially carcinogenic and highly toxic to both animals and humans.

\section{Conflict of Interest}

We declare that there are no conflicts of interest.

\section{Acknowledgements}

This study was supported by the National Science Council (NSC 99-2314-B-309-001-MY3) and the Innovative Research Center of Medicine, Chang Jung Christian University, Taiwan.

\section{References}

[1] Linch, A.L., O’Connor, G.B., Barnes, J.R., Killian Jr., A.S. and Neeld Jr., W.E. (1971) Methylene-bis-ortho-chloroaniline (MOCA): Evaluation of Hazards and Exposure Control. American Industrial Hygiene Association Journal, 32, 802-819. http://dx.doi.org/10.1080/0002889718506543

[2] Homburger, A.B.F., Boger, E., Van Dongen, C.G., Weisburger, E.K. and Weisburger, J.H. (1975) The Carcinogenic Effect of 4,4'-Methylene-bis-(2-chloroaniline) in Mice and Rats. Toxicology and Applied Pharmacology, 31, 47-54. http://dx.doi.org/10.1016/0041-008X(75)90050-2

[3] Hosein, H.R. and Van Roosmalen, P.B. (1978) Acute Exposure to Methylene-bis-ortho Chloroaniline (MOCA). American Industrial Hygiene Association Journal, 39, 496-497. http://dx.doi.org/10.1080/0002889778507795

[4] Rehn, L. (1895) Blasengeschwülste bei Fuchsin-arbeitern. Langenbecks Archiv für klinische Chirurgie, 50, 588-600.

[5] IARC (1974) IARC Monographs on the Evaluation of the Carcinogenic Risk of Chemicals to Man: Some Aromatic Amines, Hydrazine and Related Substances, n-Nitroso Compounds and Miscellaneous Alkylating Agents. International Agency for Research on Cancer, Lyon, 65-71.

[6] ATSDR (1994) Toxicological Profile for 4,4'-Methylenebis(2-chloroaniline) (MBOCA). The US Agency for Toxic 
Substances and Disease Registry, Available: tp45.pdf.

[7] NTP (2002) Notice of Availability of 10th Report on Carcinogens. National Toxicology Program, 67, 77283-77285.

[8] ATSDR (2000) Toxicological Profile for 4,4'-Methylenebis (2-Chloroaniline) (MBOCA). The US Agency for Toxic Substances and Disease Registry, Available: tp17.pdf.

[9] IARC (1987) Overall Evaluations of Carcinogenicity. An updating of IARC Monographs. International Agency for Research on Cancer, Lyon.

[10] Liu, C.S., Liou, S.H., Loh, C.H., Yu, Y.C., Uang, S.N., Shih, T.S. and Chen H.I. (2005) Occupational Bladder Cancer in a 4,4'-Methylenebis (2-Chloroaniline) (MBOCA)-Exposed Worker. Environmental Health Perspectives, 113, 771774. http://dx.doi.org/10.1289/ehp.7666

[11] Stula, E.F., Sherman, H., Zapp Jr., J.A. and Clayton Jr., J.W. (1975) Experimental Neoplasia in Rats from Oral Administration of 3,3'-Dichlorobenzidine, 4,4'-Methylene-bis-(2-chloroaniline), and 4,4'-Methylene-bis(2methylaniline). Toxicology and Applied Pharmacology, 31, 159-176. http://dx.doi.org/10.1016/0041-008X(75)90064-2

[12] Schirmacher, P., Peters, M., Ciliberto, G., Blessing, M., Lotz, J., Büschenfelde, K.H.M. and Stefan Rose-John, S. (1998) Hepatocellular Hyperplasia, Plasmacytoma Formation, and Extramedullary Hematopoiesis in Interleukin (IL)6/Soluble IL-6 Receptor Double-Transgenic Mice. The American Journal of Pathology, 153, 639-648. http://dx.doi.org/10.1016/S0002-9440(10)65605-2

[13] Xie, R., Chung, J.Y., Ylaya, K., Williams, R.L., Guerrero, N., Nakatsuka, N., Badie, C. and Hewitt, S.M. (2011) Factors Influencing the Degradation of Archival Formalin-Fixed Paraffin-Embedded Tissue Sections. Journal of Histochemistry \& Cytochemistry, 59, 356-365. http://dx.doi.org/10.1369/0022155411398488

[14] Yang, S.M., Ka, S.M., Hua, K.F., Wu, T.H., Chuang, Y.P., Lin, Y.W., Yang, F.L., Wu, S.H., Yang, S.S., Lin, S.H., Chang, J.M. and Chen, A. (2013) Antroquinonol Mitigates an Accelerated and Progressive IgA Nephropathy Model in Mice by Activating the Nrf2 Pathway and Inhibiting T Cells and NLRP3 Inflammasome. Free Radical Biology and Medicine, 6, 285-297. http://dx.doi.org/10.1016/j.freeradbiomed.2013.03.024

[15] Chen, H.I., Liou, S.H., Loh, C.H., Uang, S.N., Yu, Y.C. and Shih, T.S. (2005) Bladder Cancer Screening and Monitoring of 4,4-Methylenebis(2-chloroaniline) Exposure among Worker in Taiwan. Urology, 66, 305-310. http://dx.doi.org/10.1016/j.urology.2005.02.031

[16] Ward, E., Halperin, W., Thun, M., Grossman, H.B., Fink, B., Koss, L., Osorio, A.M. and Schulte, P. (1990) Screening Workers Exposed to 4,4'-Methylenebis (2-Chloroaniline) for Bladder Cancer by Cystoscopy. Journal of Occupational and Environmental Medicine, 32, 865-868. http://dx.doi.org/10.1097/00043764-199009000-00020

[17] IARC (2012) IARC Monographs on the Evaluation of the Carcinogenic Risk to Humans: A Review of Human Carcinogens: Chemical Agents and Related Occupations. International Agency for Research on Cancer, Lyon, Vol. 100F, 73-82.

[18] Dost, A., Straughan, J.K. and Sorahan, T. (2009) Cancer Incidence and Exposure to 4, 4'-Methylene-bis-orthochloroaniline (MbOCA). Occupational Medicine, 59, 402-405. http://dx.doi.org/10.1097/00043764-199009000-00020

[19] Stula, E.F., Barnes, J.R., Sherman, H., Reinhardt, C.F. and Zapp Jr., J.A. (1978) Urinary Bladder Tumors in Dogs from 4,4'-Methylene-bis-(2-Chloroaniline) (MOCA). Journal of Environmental Pathology, Toxicology and Oncology, 1, 3150. http://dx.doi.org/10.1016/0378-4274(83)90037-1

[20] Tobes, M.C., Brown, L.E., Chin, B. (1983) Kinetics of Tissue Distribution and Elimination of 4,4'Methylenebis-(2chloroaniline) in Rats. Toxicology Letters, 17, 69-76. http://dx.doi.org/10.1016/0378-4274(83)90037-1

[21] Farmer, P.B., Rickard, J. and Robertson, S. (1981) The Metabolism and Distribution of 4,4'-Methylenebis(2chloroaniline) (MBOCA) in Rats. Journal of Applied Toxicology, 1, 317-322. http://dx.doi.org/10.1002/jat.2550010610

[22] NTP (2011) Notice of Availability of 12th Report on Carcinogens. National Toxicology Program, 262-264.

[23] Kommineni, C., Groth, D.H., Frockt, I.J., Voelker, R.W. and Stanovick, R.P. (1979) Determination of the Tumorigenic Potential of Methylene-bis-orthochloroaniline. Journal of Environmental Pathology, Toxicology and Oncology, 2, 149171.

[24] Grundmann, E. and Steinhoff , D. (1970) Liver and Lung Tumors following 3,3'-Dichloro-4,4'-Diaminodiphenylmethane in Rats. Zeitschrift für Krebsforschung, 74, 28-39. http://dx.doi.org/10.1007/BF00524677

[25] Nesnow, S., Triplett, L.L. and Slaga, T.J. (1985) Studies on the Tumor Initiating, Tumor Promoting, and Tumor CoInitiating Properties of Respiratory Carcinogens. Carcinogenesis: A Comprehensive Survey, 8, 257-277.

[26] Steinhoff, D. and Grundmann, E. (1971) Cancerogenic Effect of 3,3'-dichlor-4,4'-Diaminodiphenylmethane in Rats. Naturwissenschaften, 58, 578. ( in German) http://dx.doi.org/10.1007/BF00598744

[27] Rozinova, E., Khalil, M. and Bonin, A.M. (1998) MOCA and Some Proposed Substitutes (Cyanacure, Conacure, Polacure 740M and Ethacure 300) as Two-Stage Skin Carcinogens in HRA/Skh Hairless Mice. Mutation Research, 398, 
111-121. http://dx.doi.org/10.1016/S0027-5107(97)00247-9

[28] Kugler-Steigmeier, M.E., Friederich, U., Graf, U., Lutz, W.K., Maier, P. and Schlatter, C. (1989) Genotoxicity of Aniline Derivatives in Various Short-Term Tests. Mutation Research, 211, 279-289. http://dx.doi.org/10.1016/0027-5107(89)90011-0

[29] Pilger, A. and Rüdiger, H.W. (2006) 8-Hydroxy-2'-Deoxyguanosine as a Marker of Oxidative Damage Related to Occupational and Environmental Exposure. International Archives of Occupational and Environmental Health, 80, 1-15. http://dx.doi.org/10.1007/s00420-006-0106-7 